\title{
Die Stellung \\ der Handelskammern im \\ Aufbau der wirtschaftlichen \\ Interessenvertretungen
}

\author{
Von \\ D吕. CHRIS;TIAN ECKERT \\ Geheimer Regierungsrat \\ ordentlicher Professor der Staatswissenschaften \\ an der Universität Köln
}

Zweite unveränderte Auflage

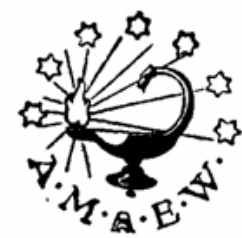

Bonn 1922

A. Marcus \& E. Webers Verlag (Dr. jur. Albert Ahn) 
Nachdruck verboten.

Alle Rechte, besonders das der Ubersetzung in fremde Sprachen behält der Verlag sich vor.

Copyright 1922 by A. Marcus \& E. Webers Verlag in Bonn. 